(RESEARCH ARTICLE)

\title{
Application of a tool based on the GUT matrix for the improvement of quality Indicators in the automotive industry
}

\author{
Cleginaldo Pereira de Carvalho ${ }^{1 *}$ and Caroline Ferreira de Castro ${ }^{2}$ \\ ${ }^{1}$ Department Of Industrial Engineering, University Of The State Of São Paulo, Faculty Of Engineering Of Guaratinguetá, \\ São Paulo, Brazil. Avenida Dr Ariberto Pereira Da Cunha 333, Pedregulho, Zipcode: 12516-410
}

Publication history: Received on 08 November 2020; revised on 15 November 2020; accepted on 16 November 2020

Article DOI: https://doi.org/10.30574/wjaets.2020.1.1.0022

\begin{abstract}
This study is related to a case study using a prioritization tool derived from the gravity, urgency and tendency (GUT) matrix, applied to a machining line in the automotive sector of a factory located in Vale do Paraíba - São Paulo (SP). This monograph addressed the implementation of a prioritization tool to aid in the definition of priorities to be work on with the aim of improving the indicators of quality of the group, reducing the rate of reworks and rejects. It is a qualitative exploratory study. The information was collected through documentary research. The information/data obtained were treated with data tabulation using spreadsheets developed in Excel Microsoft. It was found through the results that the rework index decreased $7.57 \%$ in the period from 2016 to 2019 and the reject index decreased by $3.74 \%$ in the same period. It was concluded that the objective of the general research was achieved through the validation of the priority analysis tool (derived from the GUT matrix) in a machining line as an efficient tool and which brought positive results in terms of reducing the rework and reject wastes of production.
\end{abstract}

Keywords: Priorization; GUT Matrix; Waste; Lean Manufacturing

\section{Introduction}

Applied to business, waste or "muda" in Japanese, it is any activity that does not add real value to a product or service that is being created or delivered. The elimination of wastes in how work is done is a fundamental principle of lean manufacturing (LM) which is nothing more than the strategy of operational excellence developed many years ago and widely used in business today [1].

Scraps in the production process are defined as parts produced that cannot be accepted as a final product due to some failure in their production process [2].

Quality means doing it right the first time, it's about prevention and planning and not about correction and inspection. Poor quality or defects not only result in customer dissatisfaction and damage to the company's image, but also in waste due to additional costs and time to repair, recover, rework and replace defective items [DOMINGO, rtdonline, https://www.rtdonline.com/BMA/MM/SevenWastes.pdf, Last accessed on 12/04/2020].

Therefore, the priority analysis and process mapping tools help to identify these eight major losses and work directly on the root causes to eliminate these wastes in order of criticality.

One tool used is the prioritization matrix - gravity, urgency and tendency (GUT), or simply GUT matrix, which is used whenever it is necessary to prioritize actions within a set of alternatives [3].

\footnotetext{
* Corresponding author: Cleginaldo Pereira De Carvalho

Department Of Industrial Engineering, University Of The State Of São Paulo, Faculty Of Engineering Of Guaratinguetá, São Paulo, Brazil. Avenida Dr Ariberto Pereira Da Cunha 333, Pedregulho, Zipcode: 12516-410. 
The technique was created by Charles H. Kepner and Benjamin B. Tregoe, scholars in solving organizational issues and aimed to guide more complex decisions, that is, decisions that involve many issues [3].

The general objective is to validate a priority analysis tool (derived from the GUT Matrix), in a machining line of a powertrain industry in the automotive branch located in the Paraíba Valley, in the State of São Paulo (SP).

Regarding the relevance of the theme, the GUT matrix was developed by Kepner and Tregoe. Published in 1977, this tool helps prioritize problem solving, as it helps to classify them from the perspective of severity, urgency and tendency [4]. For the assessment, the tool uses scores for the classification of each item inspected, in order to define degrees of criticality in relation to the problems found [5].

Thus, the opportunity to thoroughly analyze the usage characteristics of a tool derived from the original GUT matrix is effective.

\section{Theoretical background}

The GUT matrix is a tool widely used by companies to prioritize problems to be tackled by management, as well as to analyze the priority in which certain activities must be performed. The GUT matrix is used for several issues such as problem solving, strategies, project development, decision making.

This matrix was created by Charles H. Kepner and Benjamin B. Tregoe in 1977, where this tool helps prioritize problem solving, as it helps to classify problems from the perspective of gravity, urgency and tendency [4].

While working for Rand Corporation in the 1950s, Dr. Charles Kepner and Dr. Benjamin Tregoe, conducted research on decision-making failures in Strategic Air Command. They found that successful decision making by Air Force officers had less to do with position or career than with a logical process that an officer used to gather, organize and analyze information before acting [TRABALHOS FEITOS, https://www.trabalhosfeitos.com/ensaios/Método-KepnerTregoe/235217.html, Last accessed on 2/10/2020].

[Kepner-Tregoe History, https://www.kepner-tregoe.com/about-kt/company-overview/kepner-tregoe-history/, Last accessed on 11/07/2020] spent thousands of hours watching leaders making effective and ineffective decisions, responding to complex and repetitive challenges. His discoveries became the basis for the release of the book, The Rational Manager by McGraw Hill in 1965, which became a business classic.

GUT stands for Gravity (G), Urgency (U) and Trend (T). Each of these parameters is scored from one to five and after the score the result $\mathrm{G}$ x U x T is calculated, establishing priority parameters of the problems to be solved [6].

The great advantage of using the GUT Matrix is that it helps the manager to quantitatively assess the company's problems, making it possible to prioritize corrective and preventive actions [Sobre Administração, Matriz GUT, http://www.sobreadministracao.com/matriz-gut-guia-completo/, Last accessed on 2/10/2020].

In a corporation, solving many problems creates confusion in the manager's analysis. Since it may encounter difficulties in identifying priority issues, which deserve greater attention. It is necessary to separate the problems and then order them to solve the most relevant ones first.

In order to set up the GUT Matrix as a first step, it is necessary to list the difficulties involved in the activities carried out in an organized manner, subsequently it is necessary to assign scores for each problem mentioned, considering three main aspects: Gravity, Urgency and Tendency [7].

As for the main aspects, we have the following classifications:

- Severity: It tells you how much the weight of the analyzed difficulty is in case it happens. Certain characteristics are analyzed, such as: tasks, people, results, processes, organizations, etc. studying the results in the medium and long term, if it is not solved before;

- Urgency: The amount of time you have or need to solve the task. If the urgency is great, there is less time available to solve this problem. Questioning is recommended: The solution to this cause can wait or needs to be done immediately.?; 
- Trend: Refers to the possibility of an increase in the problem, the circumstance of the issue growing over time. It is recommended to ask: If you do not solve this problem soon, it will worsen gradually or suddenly.?

As a second step to obtain the value of the priorities, just make the product among the marks assigned as follows: (G) $\mathrm{x}$ (U) $\mathrm{x}$ (T). As a third step, after performing the calculations, a ranking of the items listed in the first step should be created, so that the one with the highest value will be ranked first in the list of priorities to be solved [Sobre Administração, Matriz GUT, http://www.sobreadministracao.com/matriz-gut-guia-completo/, Last accessed on 2/10/2020].

Once the problems' priorities for the company are discovered, the fourth step follows, which deals with the analysis of the priority problems, drawing up, as soon as possible, action plans aimed at solving or reducing the problems faced by the organization [7].

\section{Material and methods}

The methodological scope of this research converges to the area of manufacturing management, production engineering and quality, with emphasis on the GUT tool, with the researcher's mission, transforming existing knowledge using equipment and resources into new knowledge that has value for the "market" [8] through the application of a tool based on the GUT matrix in a machining process to improve the main waste identified.

This work fits into the context of applied research as it focuses on the problems present in the activities of an organization. Applied research is committed to the elaboration of diagnoses, identification of problems and search for solutions, with an exploratory objective, as it provides familiarity with the problem and involvement with bibliographic survey. The case study method will be used, as the main characteristic of this method is the intensity of the study of the object, individual, group, organization, incident or situation. It can involve a single or multiple cases, combining several techniques for data collection, such as document analysis, interviews, questionnaires and observations [9].

The evidence presented is characterized as qualitative and contains a series of interpretation techniques that seek to describe, decode, translate, and any other term related to understanding and not to the frequency of occurrence of the variables of a given phenomenon. The qualitative approach has no aversion to quantifying variables, and sometimes qualitative researchers quantify variables [8].

The company in which this research was carried out is a multinacional company focused on the automotive industry that has North America origins.

To carry out the case study, the researcher had contact with a leadership group of a machining team for a model 1.0L engine crankshaft line. This group consists of a manufacturing supervisor, a production engineer, a specialist production engineer, a quality engineer and a team coordinator. All data used for the research were provided directly by this group that worked on the elaboration, application and maintenance of the prioritization tool, based on the GUT Matrix and on the control of the quality indicators (rejects and reworks) of the team that they led.

\section{Results and discussion}

Obtaining the results of this research consisted of validating the efficiency of the prioritization tool used by the case study company, based on the GUT matrix, by analyzing the data before and after the implementation of the tool in the machining line under study.

The data was collected directly with the quality engineer who works in the case study's machining team. The data provided are related to two internal quality indicators used by the Company. The First indicator called the rework and reject index (FTTC) indicator represents the rate of good parts produced (OK quality approval) divided by the total parts produced plus the rejected parts plus the reworked parts in the year 2016 before implementation the prioritization tool. The second indicator called the scrap indicator represents the rate of good parts produced (OK quality approval) divided by the summation of the parts produced plus the rejected parts. Figure 1 illustrates the formula used to calculate these data. 


Scrap Indicator $(\%)=\frac{\text { Rejected Parts }}{\text { Good Parts Produced + Rejected Parts }}$ x $100 \quad$ The smaller the better $(\%)$
FTTC Indicator $(\%)=\frac{\text { Good Parts Produced }}{\text { Good Parts Produced + Reworked Parts + Rejected Parts }} \times 100 \quad$ The bigger the better (\%)

Figure 1 Formula for calculating the scrap and FTTC indicators of the case study

According to Table 1, it can be noted that in 2016 the scrap and FTTC indicators were below the expected goal of $98 \%$.

Table 1 Result of FTTC and scrap indicators (before)

\begin{tabular}{cccc} 
Indicator & Year & Results (\%) & Objective (\%) \\
\hline FTTC Indicator (\%) & 2016 & $89.8 \%$ & $98 \%$ \\
Scrap Indicator (\%) & 2016 & $4.51 \%$ & $0 \%$ \\
\hline
\end{tabular}

\begin{tabular}{|c|c|c|c|c|c|c|}
\hline & & $\begin{array}{c}\text { Mapeamento de Caixas de } \\
\text { Registro da Estaciio de } \\
\text { Trabalho }\end{array}$ & 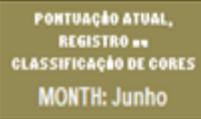 & 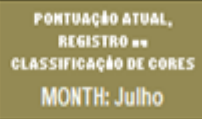 & 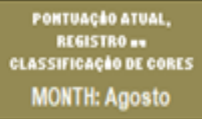 & $\begin{array}{l}\text { PROBLEMAs ou AÇÖEs (forneça um breve } \\
\text { descritivo das açöes) }\end{array}$ \\
\hline & & 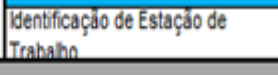 & \multicolumn{4}{|l|}{ OP\#70 } \\
\hline \multicolumn{7}{|c|}{ METRICS Trend de 90 Dias (Metric \& Classificação do Código de Cores) } \\
\hline $\mathbf{S}$ & 1 & Metric de Segurança & 0 & 0 & 0 & \\
\hline \multirow{3}{*}{$Q$} & 2 & Dados Externos da Qualidade & 0 & 0 & 0 & \\
\hline & 3 & $\begin{array}{l}\text { Dados de Qualidade do Fim da } \\
\text { Linha }\end{array}$ & 0 & 6 & 0 & Scrap devido quebra de ferramenta \\
\hline & 4 & Dados internos da Qualidade & 0 & 0 & 2 & \\
\hline \multirow{2}{*}{$\mathbf{F}$} & 5 & $\begin{array}{l}\text { Fahas/ Paradas } / 0 \text { corrència de } \\
\text { Downtime }\end{array}$ & 473 & 152 & 112 & \\
\hline & 6 & $\begin{array}{l}\text { Fahas/ Paradas / Tempo de } \\
\text { Downtime }\end{array}$ & 35,73 & 21,18 & 15,61 & \\
\hline
\end{tabular}

Figure 2 Application of the priority tool in an operation

The group of leaders involved implemented in early 2017 a board appointed by the company for continuous improvement mapping, which uses the same rules to classify priorities as the GUT matrix, in order to define priorities for eliminating waste and reducing the cost of wastes in the process.

For the definition of gravity we have the horizontal lines divided in order according to the gravity determined by the team: safety, quality and flow.

To define the urgency, we have the number of occurrences of safety, quality and flow items for the last three months, which are classified according to the colors: red (the first three worst cases); yellow (the fourth and fifth worst case) and green (after the fifth worst case).

To define the trend we have three columns that represent the record of the last three months. 
This mapping is carried out for all operations of the production line and on data analysis, the three priorities that will be worked on during the month through an action plan are defined. For the action plan, the root cause, the containment actions, the permanent actions, the preventive actions for the three priorities are defined.

Every day, all leaders meet to discuss the action plan and check the efficiency of the actions implemented through the control of new occurrences. The line's specialist engineer updates the operations mapping on a monthly basis. Figure 2 illustrates the application of the tool in an operation.

Figure 3 illustrates the application of the continuous improvement mapping board, with the mapping of all operations and the definition of the three priorities to be worked through the action plan.

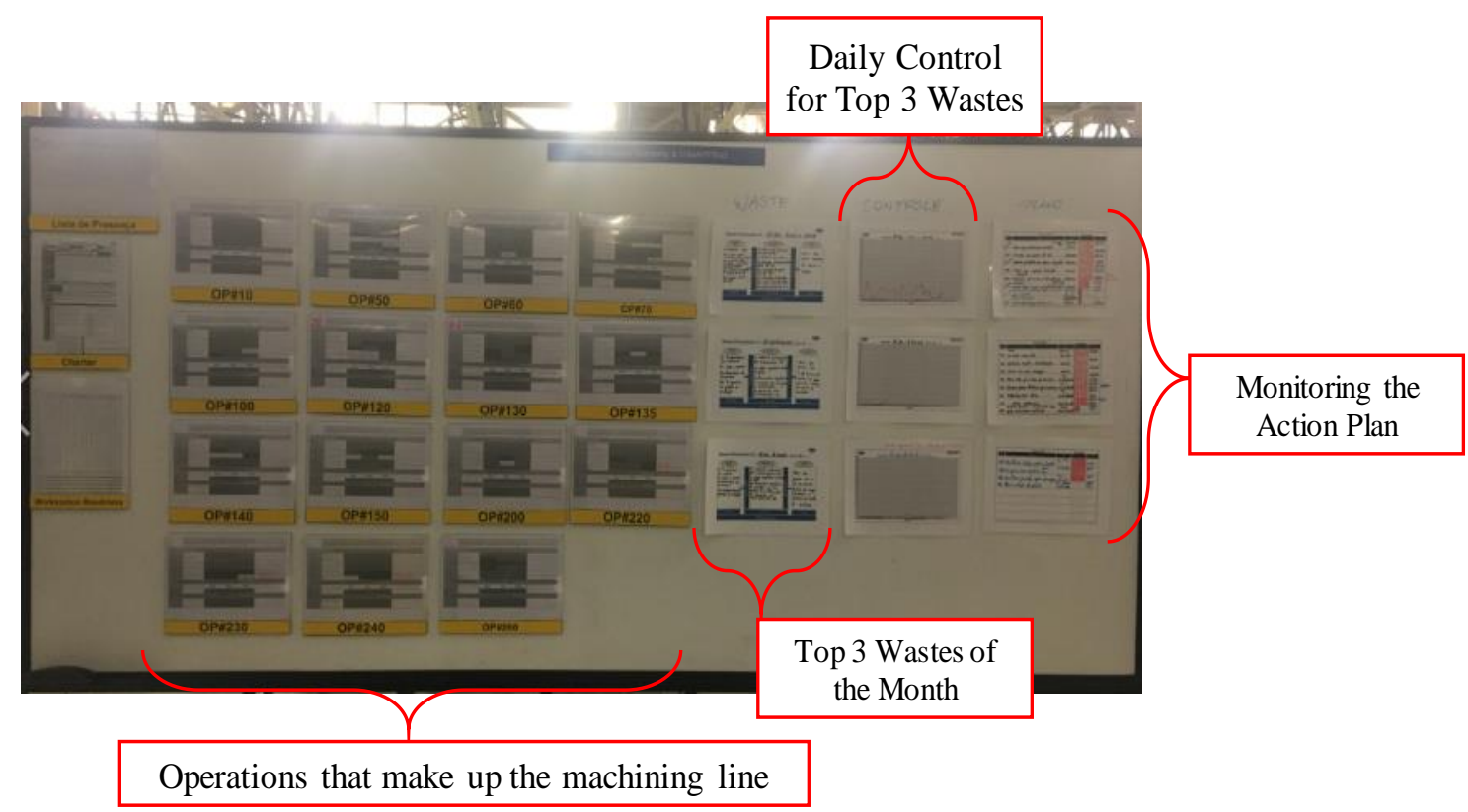

Figure 3 Implementation of a continuous improvement mapping board

After implementing and maintaining this prioritization mapping system, based on the GUT matrix in 2017 until 2019 , the team provided quality data for the FTTC and scrap indicators of the machining line, in which we can see a continuous improvement in the indicators, validating the effectiveness of the tool.

Figures 4 and 5 illustrate the evolution of the FTTC and scrap indicators, respectively.

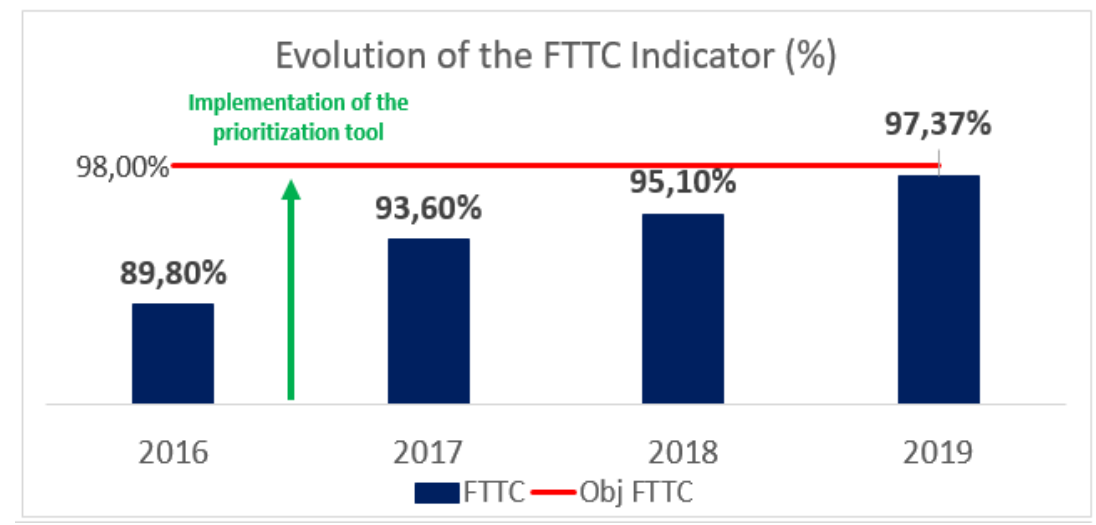

Figure 4 Evolution of the FTTC indicator 


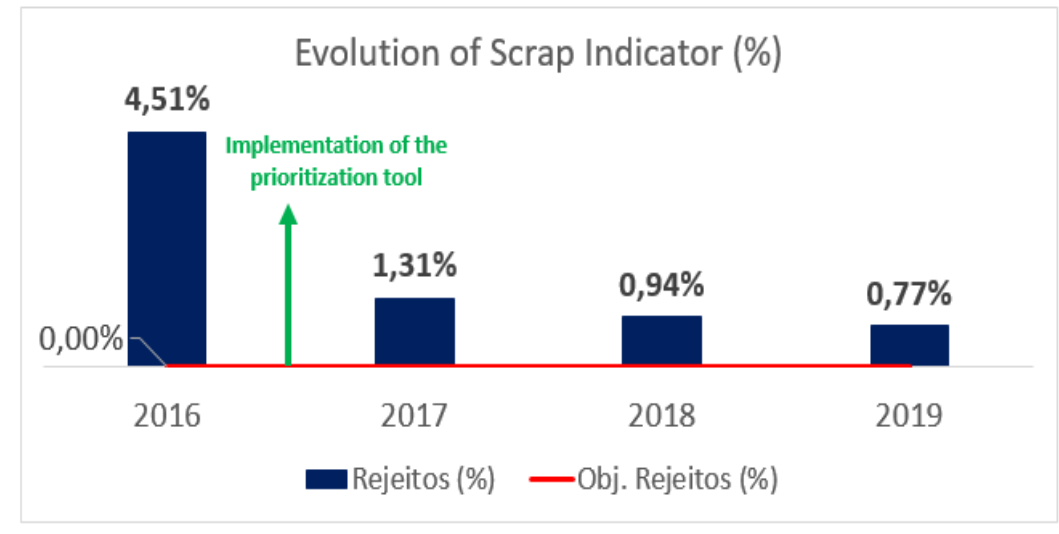

Figure 5 Evolution of the scrap indicator (\%)

It can be seen that when compared to the FTTC indicator, we had a continuous improvement of 7.57\% when comparing the year 2016 to 2019 , and for the scrap indicator we had a reduction of rejections of $3.74 \%$.

\section{Conclusion}

The general objective of the research was achieved through the validation of the priority analysis tool, derived from the GUT matrix, in a machining line as an efficient tool and which brought positive results regarding the reduction of rework waste and production line waste. The structure and application of the tool were demonstrated in order to disseminate these concepts to other scholars who have access to reading this monograph. As a limitation of the monograph in question, it is noteworthy that the case study was carried out only within an automobile company, but could also be applied in other branches of the industry. As a suggestion for future work, in addition to the GUT matrix as a prioritization tool, it is possible to apply or develop more advanced analysis tools in order to validate them.

\section{Compliance with ethical standards}

\section{Acknowledgments}

Authors wish to acknowledge the University of the State of São Paulo, Faculty of Engineering of Guaratinguetá - São Paulo - Brazil, for its assistance during the research period.

\section{Disclosure of conflict of interest}

Authors of the article claims that he has no conflict of interest.

\section{References}

[1] Pereira, R. The Seven Wastes Be Lean by identifying non-value-added activities. iSixSigma Magazine. 2009; 5(5). https://blog.gembaacademy.com/wp-content/uploads/2009/09/7_wastes_isixsigma_magazine_0909.pdf. Accessed on the 12 of april 2020.

[2] Huda, L. N. The effect of material productivity on scrap reduction on aluminum reduction pot process. IOP Conference Series: Materials Science and Engineering. 2018 ; 309. https://iopscience.iop.org/article/10.1088/1757899X/309/1/012117/pdf. Accessed on the 12 of april 2020.

[3] Costa, A. R. S. et al. Aplicação da Matriz GUT na Gestão Integrada de Resíduos Sólidos da Cidade do Recife - PE. Revista AIDIS de Ingeniería y Ciencias Ambientales: Investigación, desarrollo y práctica. 2017; 10(2). http://dx.doi.org /10.22201/iingen.0718378xe.2017.10.2.57757. Accessed on the 12 of april 2020.

[4] Neto, F. C. et al. APLICAÇÃO DA MATRIZ GUT NA INSPEÇÃO DE UMA CONSTRUÇÃO PATRIMONIAL EM FORTALEZA-CE. In: Congresso Brasileiro de Patologia das Construções - CBPAT, 2018. Campo Grande Mato Grosso do Sul - MS. Anais do Congresso Brasileiro de Patologia. Campo Grande, Mato Grosso do Sul - MS, 2018. https://www.researchgate.net/publication/324756. Accessed on the 12 of april. 2020.

[5] Verzola, S. N.; Marchiori, F. F.; Aragon, J. O. Proposta de Lista de Verificação para Inspeção Predial X Urgência das Manutenções. In: Encontro Nacional de Tecnologia do Ambiente Construído, 15., 2014, Maceio, Alagoas - AL. XV 
Encontro Nacional de Tecnologia do Ambiente Construído, Maceio, Alagoas - AL, 2014. http://doi.org/10.17012/entac/2014.300. Accessed on the 12 of april 2020.

[6] Vasconcelos, D. S. C. et al. A Utilização das Ferramentas da Qualidade Como Suporte a Melhoria do Processo de Produção - Estudo de Caso na Indústria Têxtil. In: Encontro Nacional de Engenharia de Produção, 29, 2009, Salvador - Bahia. XXIX Encontro Nacional de Engenharia de Produção, Salvador - Bahia, 2009. http://www.abepro.org.br/biblioteca/enegep2009_TN_STP_091_621_14011.pdf. Accessed on the 11 of july 2020.

[7] Pestana, M. D. et al. Aplicação Integrada da matriz GUT e da matriz da qualidade em uma empresa de consultoria ambiental. In: ANDRADE, D. F. (Org.). Gestão de Serviços Artigos Brasileiros. Belo Horizonte - Minas Gerais: Poisson.2017;2:6-15.

https://www.researchgate.net/profile/Elga_Batista_da_Silva/publication/322527146_Gestao_de_servicos_Vol ume_2/links/5a5e2782a6fdcc68fa991a41/Gestao-de-servicos-Volume-2.pdf\#page=7. Accessed on the 11 of july 2020.

[8] Cauchick-Miguel, P. A. et al. (Coord.). Metodologia de pesquisa em engenharia de produção e gestão de operações. 3. ed. Rio de Janeiro: Elsevier, 2018; 240. https://eu-ireland-custom-mediaprod.s3euwest1.amazonaws.com/Brasil/Downloads/1410/mztodologia.pdf. Accessed on the 16 of may 2020.

[9] Fleury M. T. L.; Werlang, S. R. C. Pesquisa aplicada: conceitos e abordagens. Anuário de Pesquisa GVPesquisa, $\begin{array}{llll}\text { Anuário } & \text { de } & \text { pesquisa } & 2016-2017 .\end{array}$ http://bibliotecadigital.fgv.br/ojs/index.php/apgvpesquisa/article/download/72796/69984. Accessed on the 16 of may 2020. 